\title{
KECENDERUNGAN PERTUMBUHAN TINGGI BADAN ANAK USIA 5-18 TAHUN DI INDONESIA 1940 - 2010
}

\author{
Sandjaja1, Moesijanti YE Soekatri² \\ ${ }^{1}$ Pusat Teknologi Terapan Kesehatan dan Epidemiologi Klinik \\ 2Jurusan Gizi, Politeknik Kesehatan Kemenkes Jakarta II, Jakarta \\ san_gizi@yahoo.com
}

\begin{abstract}
ABSTRAK
Tinggi badan merupakan cermin dari pertumbuhan linier tubuh. Potensi pertumbuhan tinggi badan dipengaruhi oleh tingkat sosial ekonomi, kesehatan, status gizi, konsumsi makanan, lingkungan hidup, dan genetik. Studi di banyak negara maju membuktikan bahwa tinggi badan yang semakin tinggi dan optimal pada umur yang sama sejalan dengan perbaikan tingkat kesejahteraan, disebut sebagai secular trend. Studi ini membandingkan tinggi badan anak Indonesia umur 5-18 tahun antar generasi sejak 1942 sampai 2010 dengan melakukan analisis data sekunder yaitu data dari Gorter tahun 1942 (> 30,000 anak), Yayah pada tahun 1984 (10,000 anak) dan dari RKD (Riset Kesehatan Dasar) tingkat nasional 2010 (> 60.000 anak). Hasil studi menunjukkan bahwa tinggi badan anak lebih rendah antara 7,0-13,8 cm pada laki-laki dan 6,0-10,7 cm pada perempuan dibanding dengan standar WHO. Tinggi badan anak lebih rendah di perdesaan dibanding di perkotaan, dan pada kuintil-1 pengeluaran per kapita dibanding kuintil5. Selama kurun waktu sekitar 70 tahun (1940-an - 2010) tinggi badan anak hanya bertambah 0,8-3,5 cm untuk laki laki dan 0,3-1,9 cm pada perempuan.Tinggi anak di RKD 2010 bervariasi berdasarkan tempat tinggal dan status sosial ekonomi. Anak di Jakarta lebih tinggi $2,5-6,0 \mathrm{Cm}$ pada laki laki dan 0,9-6.7 Cm pada perempuan dibandingkan dengan anak dari 32 provinsi di luar Jakarta. Status sosial ekonomi juga berhubungan dengan pertumbuhan linier yang mana mereka dengan tingkat sosial ekonomi tertinggi (kuintil-5) paling tinggi sedangkan pada kuintil-1 mempunyai tinggi badan yang terendah. Disimpulkan bahwa tinggi badan anak Indonesia usia 5-18 tahun tahun 2010 lebih rendah dari standrar WHO, dan pertumbuhan linier tahun 2010 bertambah dibandingkan dengan tahun 1940-an.
\end{abstract}

Kata kunci: kecenderungan pertumbuhan, pertumbuhan linier, tinggi badan

ABSTRACT

\section{SECULAR GROWTH OF BODY HEIGHT AMONG CHILDREN 5-18 YEAR OF AGE IN INDONESIA SINCE 1940 TO 2010}

Other studies from industrialized countries shows that improvement of height and achievement of potential growth is in accordance with better level of welfare, called secular growth. This paper aimed to provide evidence of secular growth of Indonesian children aged 5-18 year-old since 1940's up to 2010 using secondary data. The study reviewed scientific articles or studies in former Netherland Indies and Indonesia from 1942 to 2010, with large sample size, covered most areas of Indonesia, sound scientific method, aged 5 year old above. Three studies available by Gorter in 1940's ( $>30,000$ children), Yayah in 1984 (10,000 children) and secondary anthropometry data of RKD (Riset Kesehatan Dasar or Baseline Health Research) conducted nationwide in 2010 (> 60.000 children). This paper uses two older articles and analyze raw data of RKD 2010. The result shows that compared to WHO child growth standard height of Indonesian boys and girls is shorter 7.0-13.8 cm and 6.0-10.7 cm, respectively. There is only 0.8-3.5 cm in boys and 0.3-1.9 cm in girls increase of linear growth over 70 years since 1940's. Child height in RKD 2010 varied according to residence and socio-economic status. Children in Jakarta were taller 2.5-6.0 Cm in boys and $0.9-6.7 \mathrm{Cm}$ in girls compared to the rest of the country. Children from highest socio-economic status (quintile-5) is the tallest, and quintile-1 is the shortest. The difference of height is between 3.1-4.2 $\mathrm{cm}$ in boys and 1.6-3.7 in girls. It is concluded that height of Indonesian children 5-18 year-old in 2010 is lower than WHO standard and an increase of linear growth found in 2010 compared to in 1940's.

Keywords: secular trend, linear growth, body height 


\section{PENDAHULUAN}

S etiap individu pada dasarnya bisa menjadi manusia dewasa yang berkualitas, asalkan melalui proses tumbuh kembang yang baik. Banyak hal yang mempengaruhi tumbuh kembang anak, mulai dari kecukupan gizi, status kesehatan, penyakit, pola aktivitas, hingga kondisi lingkungan sekitar. ${ }^{1}$ Bila semua faktor pendukung optimal dan faktor penghambat diminimalisir, potensi tumbuh yang optimal bisa dicapai. Hal ini bisa dilihat dari tinggi badan orangtua dan anak. Jika orangtua pada saat masih kanak-kanak keadaan sosial ekonomi, kesehatan, gizi yang kurang, maka potensi pertumbuhan liniernya tidak optimal. Dan jika sudah berkeluarga mampu meningkat kehidupannya dengan keadaan sosial ekonomi yang cukup baik dan mampu memberikan pelayanan kesehatan dan gizi yang baik untuk anak-anaknya, maka potensi tumbuh anak akan optimal, sehingga pada saat anaknya dewasa tinggi badannya mempunyai potensi lebih tinggi dari orangtuanya.

Akan tetapi sering terjadi tidak semua faktor tersebut dapat dipenuhi sehingga potensi pertumbuhan linier anak tidak optimal, prevalensi pendek di Indonesia masih tinggi. Pada Riskesdas 2007 prevalensi balita pendek sebesar 36,8 persen. ${ }^{2}$ Keadaan ini berdampak pada terhambatnya potensi pertumbuhan linear pada masa usia sekolah, sampai akhir masa remaja menuju dewasa.

Pertumbuhan linier antropometri yaitu tinggi badan merupakan cermin status gizi dalam jangka panjang, bahkan sejak dalam kandungan. Anak yang tidak cukup mendapat makanan baik dari segi kuantitas dan kualitas, morbiditas yang berulang tidak dapat tumbuh sesuai dengan potensi tumbuh yang dimilikinya. Bila keadaan tidak tumbuh normal ini berlanjut, akan mempengaruhi tinggi badan pada saat dewasa. Pengalaman dari negara-negara maju menunjukkan bahwa dalam kurun waktu puluhan tahun, tinggi badan semakin tinggi seiring dengan perbaikan sosial ekonomi, kesehatan dan gizi. Fenomena tersebut yang disebut dengan secular trend bukan hanya terjadi pada orang dewasa saja tetapi juga terjadi pada remaja. Tujuan tulisan ini adalah untuk mengukur ada tidaknya secular trend tersebut pada anak umur 5-18 tahun di
Indonesia dari data yang ada dari tahun 1940an sampai 2010.

\section{METODE PENELITIAN}

Studi dilakukan dengan melakukan review referensi tentang tinggi badan remaja Indonesia usia 5-18 tahun sejak tahun 1940-an hingga 2010. Kriteria studi mencakup data antropometri (tinggi badan), umur antara 5-18 tahun, minimal 5 kelompok umur (tahun), jumlah sampel besar, daerah penelitian meliputi bagian wilayah Indonesia atau mencakup beberapa suku di Indonesia. Hanya ada tiga referensi yang hampir sesuai dengan kriteria tersebut yaitu referensi Gorter dan de Haas tahun 1939-19403, Yayah tahun $1984^{4}$ dan Laporan Riskesdas $2010 .{ }^{5}$ Banyak referensi tentang tinggi badan tersebut tetapi umumnya tidak memenuhi kriteria tersebut karena jumlah sampel terbatas atau range umur sampel kurang dari lima tahun.

Referensi pertama yaitu penelitian Gorter dan de Haas mencakup lebih dari 30.000 anak umur 6 - 15 tahun yang dilakukan beberapa tahun mulai 1939 sampai 1942 di Batavia (Jakarta). Rata-rata tinggi badan disajikan menurut jenis kelamin dari lima sukubangsa yaitu Melayu, Sunda, Jawa, Cina, dan lainnya tetapi tidak ada nilai keseluruhan dari kelima sukubangsa tersebut. Untuk mendapatkan nilai keseluruhan menurut jenis kelamin dari kelima sukubangsa tersebut penulis menghitung nilai rata-ratanya dengan memperhitungkan jumlah sampel dari masing-masing sukubangsa. ${ }^{3}$

Referensi kedua adalah penelitian Yayah tahun 1984 dikumpulkan dari 17 kabupaten/ kota di Jawa pada anak TK dan SD umur 5 - 13 tahun dengan total sampel 13,662 anak. Hasil penelitian referensi tersebut disajikan nilai ratarata tinggi badan per tiga bulan menurut jenis kelamin. Oleh karena pengelompokan umur yang berbeda tersebut, penulis melakukan analisis kembali dengan menghitung nilai ratarata menjadi kelompok umur tahunan dan jenis kelamin. ${ }^{4}$

Referensi ketiga adalah data Riskesdas 2010 yang dilakukan oleh Badan Litbang Kesehatan. Riskesdas 2010 merupakan studi potong lintang yang mengumpulkan berbagai data tentang status kesehatan penduduk Indonesia untuk semua kelompok umur di 33 provinsi yang tersebar di 441 kabupaten/kota. Metodologi lengkap Riskesdas dapat dibaca 
dalam Laporan Riskesdas 2010.5 Dari studi tersebut dapat diperoleh gambaran pencapaian indikator kesehatan terkait dengan MDGs. Salah satu variabel yang dikumpulkan adalah ukuran antropometri untuk semua umur termasuk kelompok 5-18 tahun. Walaupun ada Laporan Riskesdas 2010, tetapi penulis melakukan analisis ulang dari data sekunder. Tidak semua variabel dalam kuesioner Riskesdas 2010 dimasukkan dalam analisis tulisan ini. Variabel yang diambil untuk dianalisis adalah daerah perdesaan/ perkotaan (kuesioner blok 1 kolom 5, B1R5), jenis kelamin sampel (B4K4), umur sampel (B4K7THN), tinggi badan (B10A2B), pembobotan (weight), tingkat pengeluaran rumahtangga per kapita (kuintil). Dari variabel tersebut dipilih sampel yang memenuhi kriteria inklusi yaitu data lengkap daerah, jenis kelamin sampel, umur sampel antara 5-18 tahun, pembobotan, dan kuintil. Untuk tinggi badan sampel selain data lengkap, kriteria inklusi adalah z-score tinggi badan antara -5.0 sampai +5.0 standar WHO 2007 untuk tiap umur (tahun). ${ }^{6}$ Analisis data bivariat dengan pembobotan dilakukan untuk mengetahui nilai median tinggi badan sampel menurut umur (tahun), jenis kelamin, perkotaan/ perdesaan, dan kuintil. Nilai median tinggi badan dan bukan rata-rata tinggi badan digunakan karena standar WHO 2007 menguunakan nilai median.
Untuk mengetahui pencapaian pertumbuhan linier tinggi badan Riskesdas 2010 dibandingkan dengan standar WHO 2007, dan referensi studi antropometri yang pernah dilakukan di Indonesia sejak tahun 1940-an untuk mengetahui adanya secular trend tinggi badan.

\section{HASIL}

Sampel Riskesdas 2010 untuk kelompok umur 5-18 tahun yang ada adalah 67.309 sampel. Dari jumlah tersebut, yang memenuhi kriteria untuk dianalisis dalam tulisan ini adalah 64.960 sampel $(96,5 \%)$. Rincian sampel menurut jenis kelamin dan daerah disajikan pada Tabel 1. Jumlah sampel laki-laki (33.768 sampel) lebih banyak dibandingkan dengan perempuan (31.192 sampel). Jumlah sampel di perkotaan (32.877) hampir sama dengan sampel di perdesaan (32.083). Jumlah sampel relatif lebih banyak pada umur muda dibanding dengan umur sampel menjelang dewasa.

Hasil analisis tinggi badan disajikan pada Tabel 2. Nilai median tinggi badan anak laki-laki dan perempuan total pada umur 5 tahun sama yaitu $105,0 \mathrm{Cm}$. Mulai umur 9 tahun nilai median anak perempuan $(125,5 \mathrm{Cm})$ lebih tinggi dari laki-laki $(125,1 \mathrm{Cm})$ sampai umur 13 tahun.

Tabel 1

Jumlah Sampel Anak 5-18 Tahun menurut Umur, Jenis Kelamin, dan Daerah, Riskesdas 2010

\begin{tabular}{ccccc}
\hline \multirow{2}{*}{ Umur (tahun) } & \multicolumn{2}{c}{ Jenis kelamin } & \multicolumn{2}{c}{ Daerah } \\
& Laki-laki & Perempuan & Perkotaan & Perdesaan \\
\hline 5 & 2.404 & 2.254 & 2.318 & 2.340 \\
6 & 2.668 & 2.490 & 2.458 & 2.699 \\
7 & 2.582 & 2.479 & 2.530 & 2.531 \\
8 & 2.509 & 2.351 & 2.463 & 2.397 \\
9 & 2.676 & 2.550 & 2.526 & 2.700 \\
10 & 2.823 & 2.492 & 2.659 & 2.656 \\
11 & 2.410 & 2.127 & 2.132 & 2.405 \\
12 & 2.348 & 2.126 & 2.244 & 2.230 \\
13 & 2.452 & 2.200 & 2.332 & 2.320 \\
14 & 2.392 & 2.218 & 2.315 & 2.295 \\
15 & 2.322 & 2.073 & 2.335 & 2.060 \\
16 & 2.089 & 1.946 & 2.192 & 1.843 \\
17 & 2.142 & 1.937 & 2.249 & 1.829 \\
18 & 1.952 & 1.950 & 2.124 & 1.778 \\
\hline Total & 33.768 & 31.192 & 32.877 & 32.083 \\
\hline
\end{tabular}


Tabel 2

Median Tinggi Badan Anak 5-18 Tahun menurut Jenis Kelamin dan Daerah, Riskesdas 2010

\begin{tabular}{ccccccc}
\hline \multirow{2}{*}{ Umur (tahun) } & \multicolumn{3}{c}{ Laki-laki } & \multicolumn{3}{c}{ Perempuan } \\
\cline { 2 - 6 } & Kota & Desa & Total & Kota & Desa & Total \\
\hline 5 & 106,4 & 104,0 & 105,0 & 105,7 & 104,7 & 105,0 \\
6 & 112,6 & 110,0 & 111,0 & 111,0 & 109,9 & 110,0 \\
7 & 118,3 & 115,2 & 116,5 & 117,0 & 115,0 & 115,6 \\
8 & 122,0 & 120,0 & 120,5 & 121,2 & 120,0 & 120,2 \\
9 & 127,0 & 124,2 & 125,1 & 127,0 & 124,5 & 125,5 \\
10 & 130,6 & 128,7 & 130,0 & 133,0 & 129,4 & 130,5 \\
11 & 135,8 & 133,5 & 135,0 & 140,0 & 136,0 & 137,9 \\
12 & 142,3 & 138,0 & 140,0 & 145,5 & 141,0 & 143,5 \\
13 & 149,2 & 145,0 & 147,0 & 149,0 & 146,0 & 147,0 \\
14 & 155,0 & 151,0 & 153,5 & 150,0 & 148,5 & 150,0 \\
15 & 160,0 & 156,0 & 158,0 & 152,0 & 150,0 & 151,0 \\
16 & 162,0 & 160,0 & 160,9 & 153,0 & 151,0 & 152,2 \\
17 & 164,0 & 161,0 & 162,5 & 154,0 & 151,7 & 152,0 \\
18 & 165,0 & 161,6 & 163,0 & 154,0 & 152,0 & 153,0 \\
\hline
\end{tabular}

Tabel 3

Median Tinggi Badan Anak 5-18 Tahun menurut Kuintil Pengeluaran Rumahtangga per Kapita, Riskesdas 2010

\begin{tabular}{ccccccc}
\hline \multirow{2}{*}{ Umur (tahun) } & \multicolumn{3}{c}{ Laki-laki } & & Perem \\
\cline { 2 - 6 } & Kuintil-1 & Kuintil-3 & Kuintil-5 & Kuintil-1 & Kuintil-3 & Kuintil-5 \\
\hline 5 & 104,0 & 105,5 & 108,0 & 103,0 & 105,5 & 107,5 \\
6 & 110,0 & 111,6 & 115,0 & 108,4 & 110,0 & 112,6 \\
7 & 115,0 & 116,5 & 120,0 & 114,5 & 115,1 & 118,0 \\
8 & 119,0 & 121,0 & 123,0 & 119,5 & 120,3 & 123,0 \\
9 & 123,5 & 125,1 & 129,0 & 123,3 & 126,7 & 129,3 \\
10 & 127,9 & 130,0 & 135,0 & 129,0 & 131,4 & 135,5 \\
11 & 132,7 & 135,0 & 138,1 & 135,0 & 138,2 & 141,6 \\
12 & 136,7 & 140,5 & 145,0 & 140,0 & 142,6 & 148,5 \\
13 & 143,0 & 148,5 & 152,7 & 145,0 & 148,0 & 150,5 \\
14 & 150,0 & 154,2 & 157,0 & 148,0 & 150,0 & 152,0 \\
15 & 155,0 & 159,0 & 161,7 & 150,0 & 151,2 & 153,0 \\
16 & 159,3 & 161,5 & 163,5 & 151,0 & 152,4 & 153,5 \\
17 & 160,5 & 163,0 & 164,9 & 151,0 & 153,0 & 154,4 \\
18 & 160,0 & 163,2 & 165,9 & 152,0 & 153,5 & 154,2 \\
\hline
\end{tabular}

Hal ini menunjukkan proses pubertas lebih awal pada perempuan dibandingkan dengan laki-laki. Nilai median tinggi badan pada umur 13 tahun sama antara anak laki-laki dan perempuan $(147,0 \mathrm{Cm})$, dan sesudah umur tersebut median tinggi badan anak laki-laki lebih tinggi dibanding perempuan. Pada umur 18 tahun median tinggi badan pada anak laki-laki $163 \mathrm{Cm}$ dan anak perempuan 153,0 Cm. Jika nilai median tinggi badan dibandingkan antara anak yang tinggal di perkotaan dan perdesaan terlihat bahwa umumnya anak yang tinggal di perkotaan lebih tinggi dibanding anak yang tinggal di perdesaan. Perbedaan tersebut berkisar antara 2,0 - 4,3 cm pada anak laki-laki dan antara 1,0-4,5 cm pada anak perempuan.

Riskesdas 2010 mengumpulkan data tentang pengeluaran rumahtangga sebagai proksi terhadap status sosial ekonomi. Pengeluaran rumahtangga tersebut dibagi menjadi dua kelompok besar yaitu pengeluaran untuk makanan dan bukan untuk makanan. 
Pengeluaran untuk makanan terdiri dari 14 jenis pengeluaran, sedangkan pengeluaran bukan makanan terdiri dari 6 jenis. Dari data tersebut diketahui pengeluaran rumahtangga per kapita, yang kemudian dikelompokkan menjadi 5 yaitu kuintil-1 adalah rumahtangga miskin sampai dengan kuintil-5 adalah rumahtangga kaya. Nilai median tinggi badan menurut kuintil disajikan pada Tabel 3, tetapi hanya untuk kelompok kuintil-1, kuintil-3, dan kuintil-5.

Terlihat dalam Tabel 3 bahwa nilai median tinggi badan kuintil-1 pada semua umur secara konsisten selalu yang paling rendah baik pada anak laki-laki maupun perempuan. Sebaliknya nilai median tinggi bada kuintil-5 konsisten selalu paling tinggi, sedangkan pada kuintil-3 berada di antaranya. Perbedaan nilai median tinggi badan antara kuintil-1 dan kuintil-5 pada umur yang sama berkisar antara 4,0 - 9,7 Cm pada anak laki-laki dan $2,3-8,5 \mathrm{Cm}$ pada anak perempuan.

Tabel 4 menyajikan median tinggi badan anak di DKI Jakarta dibandingkan dengan 32 provinsi lainnya karena untuk membandingkan dengan penelitian Gorter dan de Haas yang dilakukan di Batavia.

Terlihat dalam Tabel 4 bahwa nilai median tinggi badan anak laki-laki dan perempuan di
DKI Jakarta selalu lebih tinggi dibanding dengan 32 provinsi lainnya. Pada anak laki-laki perbedaan tersebut antra $2,5-6,0 \mathrm{Cm}$, terkecil pada umur di bawah 10 tahun dan semakin berbeda pada umur antara 10-15 tahun, dan menurun kembali pada umur 16 tahun atau lebih. Pada anak perempuan perbedaan tersebut antara 1,6-6,7 Cm dengan pola yang sama dengan laki-laki dimana perbedaan paling tinggi pada umur 10-15 tahun dan kembali menurun pada umur 16 tahun atau lebih. Tetapi bila dibandingkan dengan tahun 1940-an terjadi kenaikan tinggi badan anak umur $6-15$ tahun antara 2,5 - 10,8 $\mathrm{Cm}$ pada anak laki-laki dan 1,1 - 9,1 pada anak perempuan

Nilai median tinggi badan kelompok umur 5-18 tahun di Indonesia tersebut dibandingkan dengan standar WHO 2007 disajikan pada Gambar 1 - 4. Pada Gambar 1 terlihat bahwa tinggi badan anak laki-laki Indonesia lebih rendah dibanding standar WHO 2007. Selisih tinggi badan tersebut berkisar antara 7,0-13,8 $\mathrm{Cm}$ lebih rendah dibanding standar WHO. Perbedaan tersebut lebih terlihat di daerah perdesaan yaitu antara $8,9-15,3 \mathrm{Cm}$ sedangkan di perkotaan antara 6,2-12,2 Cm. Semakin bertambah umur semakin besar selisih tinggi badan tersebut.

Tabel 4

Median Tinggi Badan Anak 5-18 Tahun menurut Jenis Kelamin di DKI Jakarta dan 32 Provinsi Lain, Riskesdas 2010

\begin{tabular}{ccccccc}
\hline \multirow{3}{*}{ Umur (tahun) } & \multicolumn{3}{c}{ Laki-laki } & \multicolumn{3}{c}{ Perempuan } \\
\cline { 2 - 7 } & $\begin{array}{c}\text { DKI } \\
\text { Jakarta }\end{array}$ & $\begin{array}{c}\text { 32 Prov } \\
\text { lain }\end{array}$ & 1940-an & $\begin{array}{c}\text { DKI } \\
\text { Jakarta }\end{array}$ & $\begin{array}{c}\text { 32 Prov } \\
\text { lain }\end{array}$ & 1940-an \\
\hline 5 & 108.3 & 105.0 & - & 109.0 & 105.0 & - \\
6 & 113.5 & 111.0 & 111.0 & 111.6 & 110.0 & 110.5 \\
7 & 120.0 & 116.5 & 115.1 & 120.0 & 115.5 & 115.1 \\
8 & 125.0 & 120.4 & 119.3 & 122.7 & 120.1 & 119.5 \\
9 & 130.2 & 125.0 & 124.3 & 130.0 & 125.2 & 124.2 \\
10 & 135.0 & 130.0 & 128.2 & 137.0 & 130.3 & 129.0 \\
11 & 140.0 & 134.6 & 132.1 & 141.0 & 137.5 & 134.5 \\
12 & 145.2 & 140.0 & 136.6 & 149.1 & 143.0 & 140.0 \\
13 & 150.0 & 147.0 & 142.7 & 150.0 & 147.0 & 144.4 \\
14 & 158.0 & 153.0 & 149.4 & 153.0 & 150.0 & 147.2 \\
15 & 164.0 & 158.0 & 153.2 & 155.0 & 151.0 & 148.7 \\
16 & 164.5 & 160.5 & - & 153.0 & 152.1 & - \\
17 & 166.0 & 162.2 & - & 156.0 & 152.5 & - \\
18 & 165.6 & 163.0 & - & 154.0 & 153.0 & - \\
\hline
\end{tabular}




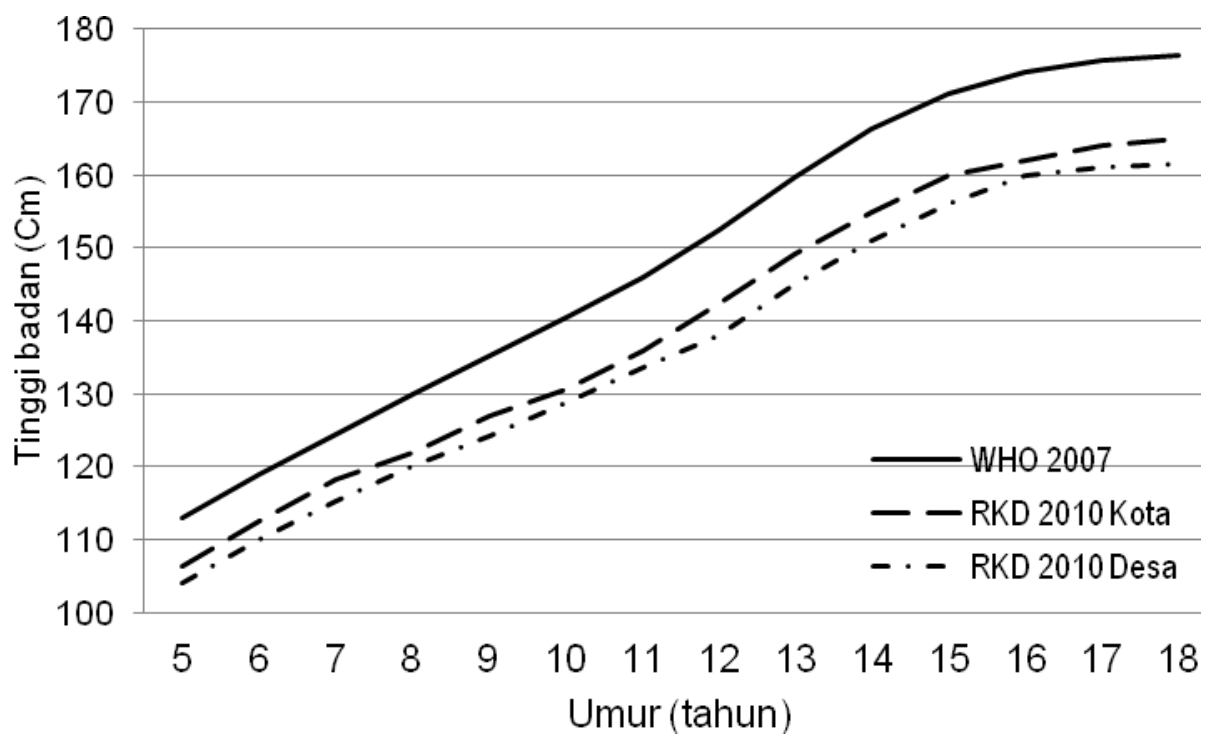

Gambar 1

Pola Pertumbuhan Anak Laki-Laki 5-18 Tahun menurut Daerah, Riskesdas 2010

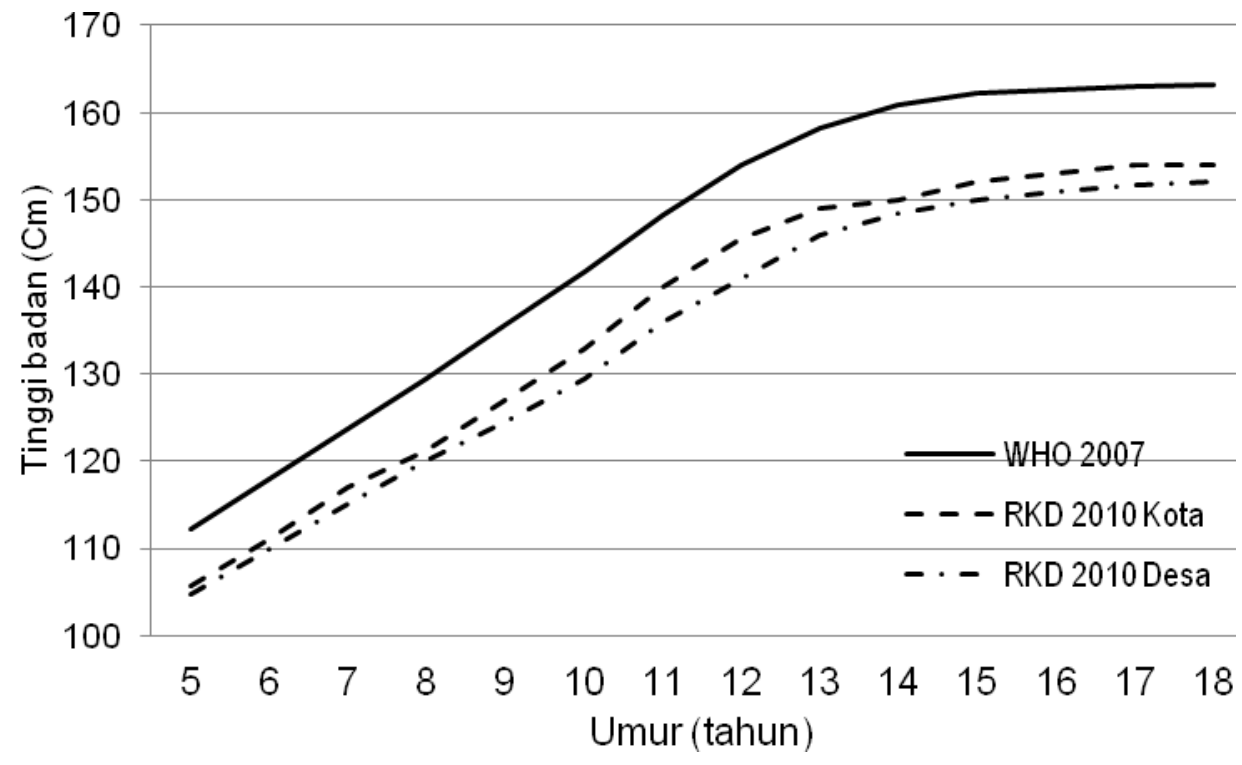

Gambar 2

Pola Pertumbuhan Anak Perempuan 5-18 Tahun menurut Daerah, Riskesdas 2010

Pada Gambar 2 disajikan grafik pertumbuhan anak perempuan. Sama seperti halnya pada anak laki-laki, tinggi badan anak perempuan lebih rendah dibandingkan dengan standar WHO. Selisih tinggi badan anak perempuan tersebut berkisar antara 6,0-10,7 $\mathrm{Cm}$, bervariasi di daerah perkotaan $6,5-10,9$ $\mathrm{Cm}$ dan 7,5-13,0 $\mathrm{Cm}$ di perdesaan. Semakin bertambah umur semakin besar selisih tinggi badan tersebut.
Hasil analisis tinggi badan juga dilakukan menurut tingkat pengeluaran rumahtangga per kapita (kuintil) dibanding standar WHO disajikan pada Gambar 3 dan 4. Hasil analisis anak lakilaki dibandingkan dengan standar WHO 2007 pada Gambar 3 menunjukkan bahwa selisih tinggi badan tertinggi terjadi pada kuintil-1 yaitu antara 8,9-16,7 Cm. Sedangkan selisih pada kuintil-5 pada tingkat pengeluaran rumahtangga tertinggi lebih rendah yaitu antara 4,9-10,9 
$\mathrm{Cm}$. Perbedaan dibanding dengan standar WHO tersebut lebih terlihat pada umur antara 12 - 15 tahun. Hal ini diduga karena pengaruh masa pubertas yang lebih lambat dibanding dalam standar WHO. Semakin bertambah umur semakin besar selisihnya dibanding standar WHO.

Hasil analisis pada anak perempuan dibandingkan dengan standar WHO 2007 pada Gambar 4 menunjukkan bahwa selisih tinggi badan tertinggi terjadi pada kuintil-1 yaitu antara $9,2-14,0 \mathrm{Cm}$. Sedangkan selisih pada kuintil-5 lebih sedikit yaitu antara 4,7 - 9,2 Cm. Perbedaan dibanding dengan standar WHO tersebut lebih terlihat pada umur antara $12-15$ tahun. Hal ini diduga karena pengaruh masa pubertas yang lebih lambat. Semakin bertambah umur semakin besar selisihnya dibanding standar WHO.

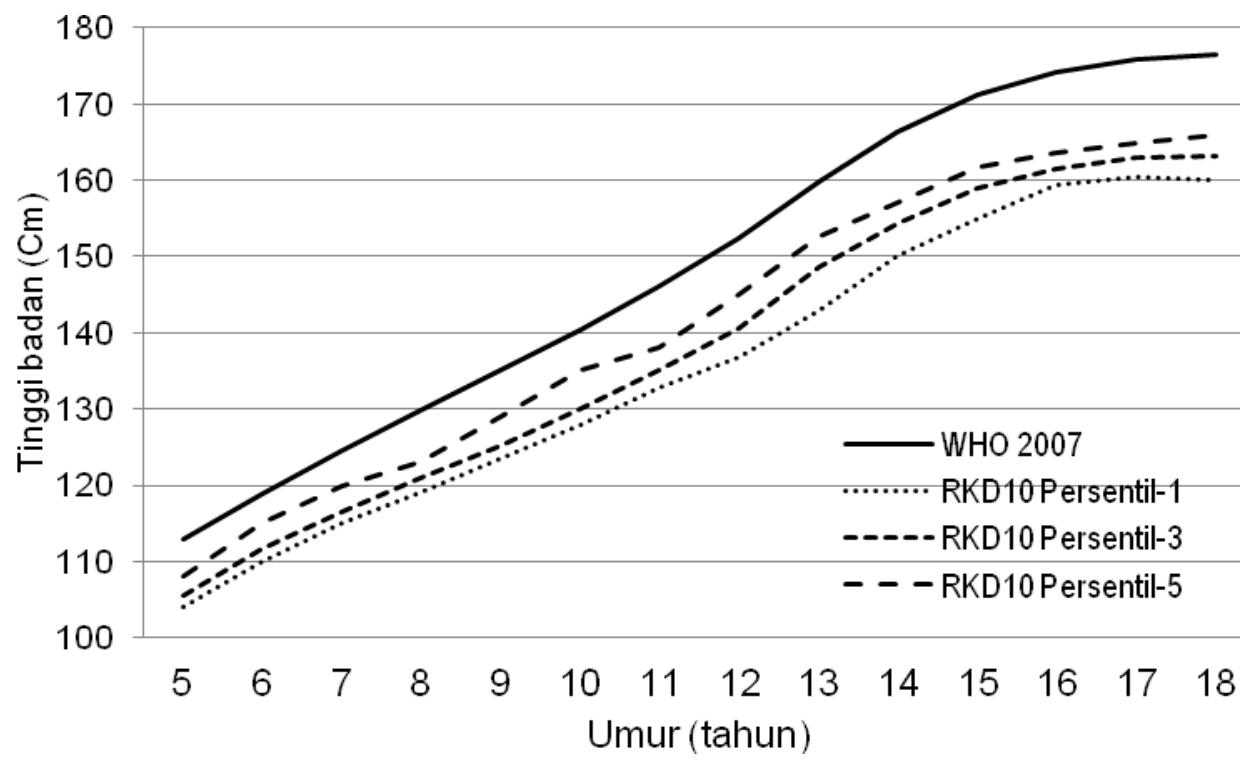

Gambar 3

Pola Pertumbuhan Anak Laki-Laki 5-18 Tahun menurut

Persentil Sosial Ekonomi Rumahtangga, Riskesdas 2010

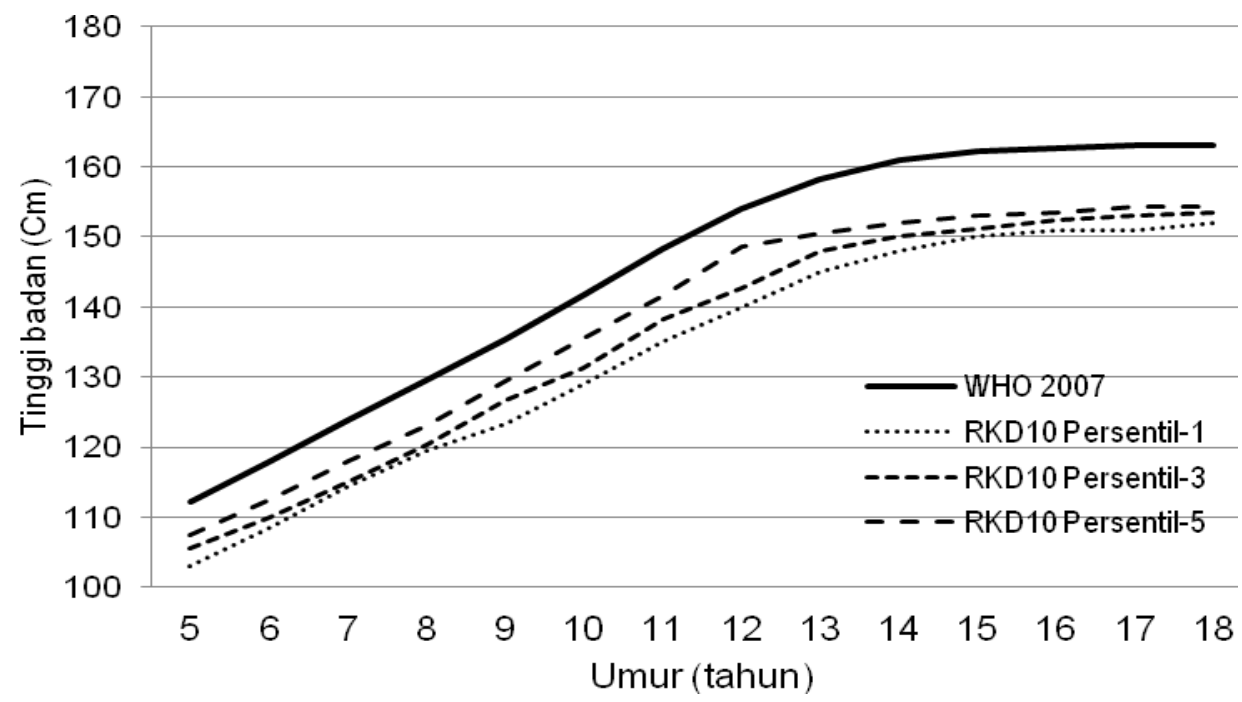

Gambar 4

Pola Pertumbuhan Anak Perempuan 5-18 Tahun menurut Persentil Sosial Ekonomi Rumahtangga, Riskesdas 2010 


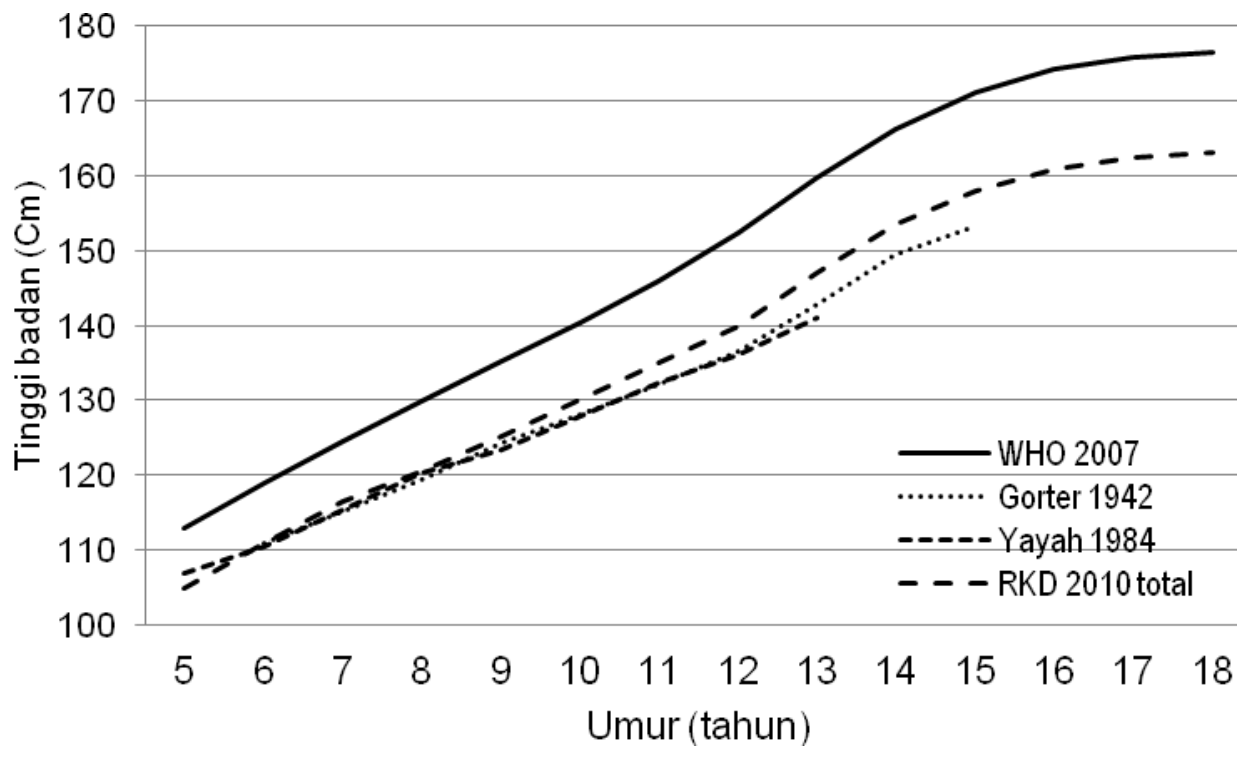

Gambar 5

Tren Pertumbuhan Anak Laki-Laki 5-18 Tahun di Indonesia

Sejak 1940 - 2010 menurut Beberapa Studi

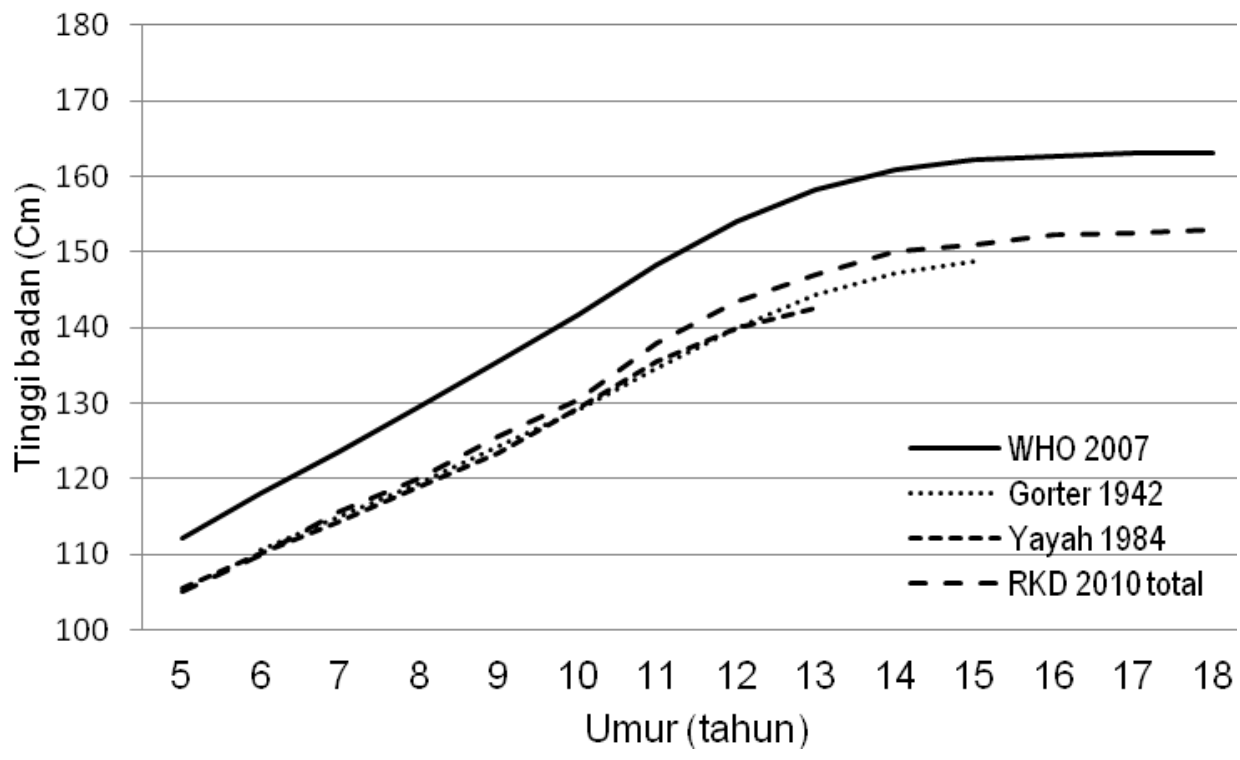

Gambar 6

Tren Pertumbuhan Anak Perempuan 5-18 Tahun di Indonesia sejak 1940 - 2010 menurut Beberapa Studi

Gambar 5 menunjukkan perbandingan pertumbuhan anak laki-laki Indonesia dalam kurun waktu 1940-an sampai 2010 dari 3 studi. Bila dibandingkan dua studi yaitu antara studi Gorter 1939-1942 dan Yayah 1984, tinggi badan anak laki-laki $6-13$ tahun ada perbedaan antara $-1,6$ sampai $+1,0 \mathrm{Cm}$. Nilai positif dan negatif berarti ada penurunan ataupun kenaikan tinggi badan yang menunjukkan bahwa hampir tidak ada perbedaan tinggi badan anak laki-laki dalam kurun waktu 1940-an sampai 1984. Bila studi Riskesdas 2010 dibandingkan dengan studi Gorter dan Yayah, terlihat bahwa pada umur 5 9 tahun tinggi badan tahun 2010 berbeda antara $-1,9$ sampai $+1,7 \mathrm{Cm}$. Hal ini menunjukkan bahwa hampir tidak ada perubahan tinggi badan dalam kurun waktu 1940-an hingga 2010 pada 
anak umur kurang dari 10 tahun. Sedangkan pada umur 10 - 15 tahun berbeda antara 1,9 $5,9 \mathrm{Cm}$ yang menunjukkan secular growth terlihat lebih nyata pada remaja dibandingkan dengan umur yang lebih muda.

Gambar 6 menunjukkan perbandingan pertumbuhan anak perempuan Indonesia dalam kurun waktu 1940-an sampai 2010 dari 3 studi. Bila dibandingkan dua studi antara studi Gorter 1939-1942 dan Yayah 1984, tinggi badan anak perempuan $6-13$ tahun perbedaan antara 1,7 sampai $+1,0 \mathrm{Cm}$. Nilai positif dan negatif berarti ada penurunan ataupun kenaikan tinggi badan yang menunjukkan bahwa hampir tidak ada perbedaan tinggi badan anak perempuan dalam kurun waktu 1940-an sampai 1984. Bila studi Riskesdas 2010 dibandingkan dengan studi Gorter dan Yayah, terlihat bahwa pada umur 5 - 9 tahun tinggi badan tahun 2010 berbeda antara - 0,5 sampai $2,2 \mathrm{Cm}$. Sedangkan pada umur 10 - 15 tahun berbeda antara 1,5 - 4,3 Cm. Hal ini menunjukkan bahwa secular growth terlihat lebih nyata pada remaja putri 10 tahun ke atas dibandingkan dengan umur yang lebih muda, sama seperti pada anak laki-laki.

\section{BAHASAN}

Pengaruh kemajuan di tingkat negara, masyarakat dan rumahtangga dalam status sosial ekonomi, kesehatan, konsumsi makanan yang cukup baik, pola aktivitas fisik, dan faktor lingkungan yang lebih baik berpengaruh pada tingkat secular trend yang berbeda saat balita, remaja, masa pubertas hingga dewasa muda. Hal ini sudah dibuktikan dari berbagai penelitian. 1,7,8,9,10,11,12 Sampai tingkat tertentu kemajuan suatu masyarakat potensi pertumbuhan linier terus naik hingga mencapai titik tertinggi potensi tumbuhnya.

Secular trend bukan kejadian homogen dan konsisten yg menyangkut bukan saja tinggi tetapi juga berat badan, bentuk tubuh, tetapi juga ukuran tubuh lainnya. Terjadinya pembentukan tulang karena proses osteoklas dan osteoblast dengan kecepatan berbeda, serta di bagian tubuh berbeda menentukan ukuran tubuh seseorang. Banyak faktor baik sendiri maupun bersama mempengaruhi pertumbuhan linier hingga mencapai potensi genetiknya. Intake energi, protein dan beberapa micronutrien merupakan determinan utama pertumbuhan. Pada masa pubertas pertumbuhan diatur oleh hormon gonadotropin, leptin, steroid, dan growth hormone. ${ }^{9}$

Sebelum membandingkan antara studi 1940-an (Gorter dan de Haas, 1947)33, (Yayah, 1984) ${ }^{4}$ dan Riskesdas $2010^{5}$ perlu dicermati perbedaan ketiga studi tersebut. Perbedaan pertama adalah daerah penelitian. Pada studi 1940-an studi hanya dilakukan di Batavia (Jakarta) pada anak sekolah. Asumsinya adalah anak yang mampu sekolah saat itu adalah anak dari keluarga Indonesia yang tingkat sosial ekonominya tinggi dan partisipasi sekolah masih rendah dari rumahtangga sosial ekonomi menengah dan rendah. Selain itu daerah studi hanya di Batavia (Jakarta) saja dan tidak mencakup seuruh Hindia Belanda (Indonesia). Pada studi 1984 sampel adalah anak sekolah TK dan SD dan hanya dilakukan di Pulau Jawa. Sedangkan Riskesdas 2010 dilakukan di seluruh provinsi Indonesia. Perbedaan kedua adalah angka yang dibandingkan. Pada studi 1940-an dan 1984 angka yang tersedia dalam referensi adalah nilai rata-rata (mean) tinggi badan, bukan nilai median. Sedangkan pada tulisan ini analisis data Riskesdas 2010 dan standar WHO yang digunakan adalah angka median. Data studi tahun 1940-an dan 1984 tidak tersedia sehingga tidak bisa dianalisis nilai mediannya. Tetapi hasil analisis data Riskesdas 2010, nilai rata-rata (mean) dan median berbeda antara $0,0-0,8 \mathrm{Cm}$, sehingga pembandingan antara nilai rata-rata-pada studi 1940-an, 1984 dengan nilai median pada Riskesdas 2010 masih bisa dilakukan.

Hasil analisis ini menunjukkan bahwa ukuran tinggi badan anak Indonesia umur 5 18 tahun masih di bawah standar WHO baik untuk anak laki-laki maupun perempuan. Hasil studi menunjukkan bahwa tinggi badan lebih rendah antara 6,2 - 15,3 Cm pada anak laki-laki dan $6,5-13,0 \mathrm{Cm}$ pada anak perempuan. Tingginya perbedaan tersebut berkaitan dengan prevalensi pendek (stunting) baik pada anak balita maupun anak 5-18 tahun. Prevalensi pendek pada anak balita Riskesdas 2007 dan 2010 masih 36,8 dan 35,6 persen. Sedangkan pada anak 6-12 tahun, 13-15 tahun, 16-18 tahun pada Riskesdas 2010 prevalensi pendek masing-masing 35,6, 35,2, dan 31,2 persen. ${ }^{5}$ Dengan prevalensi pendek yang masih tinggi tersebut anak tidak mampu mengejar ketinggalan pertumbuhan tinggi badan. 
Perbedaan tinggi badan terjadi pada anak di perkotaan dan perdesaan maupun antar kuintil pengeluaran rumahtangga per kapita. Jika nilai median tinggi badan dibandingkan antara anak yang tinggal di perkotaan dan perdesaan terlihat bahwa umumnya anak yang tinggal di perkotaan lebih tinggi dibanding anak yang tinggal di perdesaan. Perbedaan tersebut berkisar antara 2,0 - 4,3 $\mathrm{Cm}$ pada anak laki-laki dan antara 1,0 - 4,5 $\mathrm{Cm}$ pada anak perempuan. Pada studi Tan (12) 1932-37 di Jakarta perbedaan tinggi badan juga ditemukan menurut sukubangsa Jawa Sumatra dan Tionghoa.

Selain menurut daerah, studi Riskesdas 2010 ini juga menemukan perbedaan nilai median tinggi badan antara kuintil-1 dan kuintil5 pada umur yang sama berkisar antara 4,0 9,7 Cm pada anak laki-laki dan 2,3 - 8,5 Cm pada anak perempuan. Dengan demikian perbedaan lebih nyata menurut kuintil pengeluaran rumahtangga dibanding daerah. Walaupun ada kemungkinan perpindahan tempat tinggal ataupun perubahan status sosial ekonomi, tetapi perbedaan tinggi badan tersebut masih terjadi. Perbedaan tinggi tersebut tidk terlepas dari prevalensi pendek Riskesdas 2010. Prevalensi pendek anak 6-12 tahun di perkotaan dan perdesaan masingmasing 29,3 dan 41,5 persen. Demikian juga perbedaan prevalensi pendek antara kuintil-1 dan kuintil-5 sangat berbeda yaitu 45,6 dan 21,7 persen. ${ }^{5}$

Hasil studi selama kurun waktu 70 tahun (1940-an - 2010) secara umum tinggi badan umur 5-9 tahun relatif sama pada laki-laki $(-1,9$ sampai $+1,7 \mathrm{Cm})$ maupun perempuan $(-0,5$ sampai $+2,2 \mathrm{Cm}$ ). Sedangkan pada umur $10-$ 15 tahun lebih tinggi hanya $1,9-5,9 \mathrm{Cm}$ pada laki-laki dan 1,5 - 4,3 $\mathrm{Cm}$ pada perempuan (Gambar 5 dan 6). Pola secular trend yang lebih terlihat ada remaja dibandingkan dengan usia kurang dari 10 tahun terjadi juga di negaranegara lain. ${ }^{15}$ Jika studi 1940 -an yang dilakukan di Jakarta dibandingkan dengan Riskesdas di daerah yang sama hanya di DKI Jakarta terlihat terjadinya kenaikan tinggi badan anak umur 615 tahun antara 2,5-10,8 $\mathrm{Cm}$ pada anak laki-laki dan 1,1-9,1 Cm pada anak perempuan.

Secular trend tersebut masih lebih rendah dibandingkan dengan studi terjadi di negara maju. Di sebagian besar negara Eropa, tinggi badan rata-rata naik 1-2 $\mathrm{Cm}$ pada umur 5-7 tahun, 2-3 Cm pada umur 10-14 tahun. ${ }^{7}$ Studi di India tinggi badan anak perempuan umur 18 tahun hasil tahun 1992 dibanding 2011 naik antara 0-4.5 Cm. ${ }^{10}$ Studi di Eropa menunjukkan selama kurun waktu 150 tahun terjadi peningkatan tinggi badan $15-19 \mathrm{Cm}$ pada usia dewasa yang artinya rata-rata naik $1 \mathrm{Cm}$ per dekade. Studi tersebut juga menunjukkan masa pubertas lebih awal. ${ }^{15}$

Pertumbuhan sosial ekonomi tinggi sejak akhir PD-II di Eropa termasuk dalam hal konsumsi makanan merupakan faktor utama pertumbuhan linier dan ukuran tubuh yang lain. Secular trend pertumbuhan linier tinggi badan akan berakhir bila tidak ada perbaikan sosial ekonomi. ${ }^{8}$ Di Brandenburg, Jerman studi yang dilakukan Scheffler antara 1999-2009 pada anak 6-12 tahun berat badan, IMT, lemak tubuh naik, tapi tinggi badan justru turun. Asumsi penurunan tinggi ini terjadi karena berbagai faktor yaitu asumsi karena penurunan pertumbuhan ekonomi, pola aktivitas fisik rendah, dan perubahan konsumsi makanan. ${ }^{13}$

Saat ini di negara maju secular trend sudah hampir selesai untuk tinggi badan, tetapi ukuran antropometri lain seperti berat badan dan ukuran tubuh lain masih terjadi perubahan yang terkait dengan perubahan pola makan dan aktivitas fisik. Sejak 1975 di Moskwa, Rusia, berat badan wanita umur 15 tahun turun $2 \mathrm{Kg}$, lingkaran dada turun $3 \mathrm{~cm}$, lingkaran pelvis turun, indeks massa tubuh (IMT) turun dari 21 menjadi $20 .{ }^{7}$

Hasil studi ini menunjukkan bahwa tinggi badan anak remaja Indonesia 5-18 tahun masih di bawah standar WHO dan pertumbuhan linier tahun 2010 bertambah dibandingkan dengan tahun 1940-an.

\section{SIMPULAN DAN SARAN}

\section{Simpulan}

Dari tulisan ini disimpulkan bahwa tinggi badan anak Indonesia usia 5-18 tahun tahun 2010 ternyata masih lebih rendah dibandingkan dengan standar WHO. Jika dibandingkan dengan tahun 1940-an selama kurun waktu 70 tahun hingga 2010, pertumbuhan linier atau yang disebut dengan secular trend, tetapi lebih rendah dibanding yang terjadi di negara-negara lain. Tinggi badan hanya bertambah 0,8-3,5 cm pada anak laki-laki dan 0,3-1,9 cm pada anak perempuan. 


\section{Saran}

Pencapaian tinggi badan ternyata berbeda menurut tingkat sosial ekonomi, tempat tinggal, maupun daerah. Karena itu disarankan agar pemerataan pembangunan, pelayanan kesehatan, dan peningkatan gizi harus dilakukan, terutama pada kelompok masyarakat, daerah, sosial ekonomi tertentu agar dapat memacu potensi optimal pertumbuhan linier anak.

\section{UCAPAN TERIMA KASIH}

Terima kasih disampaikan untuk Badan Penelitian dan Pengembangan, Kementerian Kesehatan Rl untuk memberi izin menggunakan data RKD 2010.

\section{RUJUKAN}

1. Tanner JM. Growth at adolescence. Oxford: Blackwell Scientific Publication, 1962

2. Badan Litbang Kesehatan. Riset Kesehatan Dasar (Riskesdas) 2007. Laporan Nasional. Jakarta: Badan Litbang Kesehatan, 2008.

3. Gorter FJ, de Haas JH. Gewicht en lengte van 30.000 schoolkinderen te Batavia. Maanschrift voor Kindergeneeskunde Jaargang 1947;15(5):12-18.

4. Yayah $H$, Sandjaja, Jahari $A B$, Kartono $D$, Sulaiman Z, Herman S, et al. Antropometri anak sekolah taman kanak-kanak dan sekolah dasar untuk standar nasional. Bogor, Puslitbang Gizi, 1984.

5. Badan Litbang Kesehatan. Riset Kesehatan Dasar (Riskesdas) 2010. Laporan Nasional. Jakarta: Badan Litbang Kesehatan, 2010.
6. The WHO Child Growth Standard. Growth Reference 5-19 years. Available: from www. who.int/childgrowth/standrd/en/.

7. Godina E. Secular trend: History and perspectives. Human Physiol.2009; 35: 128-135.

8. Murata M, Hibi I. Nutrition and the secular trend of growth. Hormone Research in Pediatrics. 1992; 38 (Suppl 1): 89-96.

9. Rogol AD, Roemmich JN, Clark PA. Growth at puberty. J of Adolescent Health 2002; 31:192-200.

10. Bhatia V. Growth charts, the secular trend and the growing concern of childhood obesity. National Medical Journal of India 2011;24 (5): 260-262.

11. Gigante DP, Horta BL, Lima RC, Barros FC, Victora CG. Early life factors are determinants of female height at age 19 years in a population-based birth cohorts (Pelotas, Brazil). J Nutr.2006;136:473-478.

12. Bogin B. Keep R. Pattern of Human Growth. 2nd ed. Cambridge: Cambridge University Press, 1999.

13. Scheffler C, Ketelhut K, Mohasseb I. Does physical education modify the body composition? Results of a longitudinal study of pre-school children. Anthropol Anz.2007; 65: 193-201.

14. Tan ED, Soekonto R, de Haas JH. Kleutergroei in Batavia. Geneeskundig Tijdschrift voor Nederlandsch_Indie. Afl.1938; 52(78):16-22..

15. Hermanussen M, Godina E, Ruhli FJ, Blaha $\mathrm{P}$, Boldsen JL, van Buuren S, et al. Growth variation, final height, and secular trend. Proceedings of thew $17^{\text {th }}$ Aschauer Soiree, $7^{\text {th }}$ November 2009. J of Comparative Human Biology 20m10;61: 277-284. 
